\title{
MEMACU SEMANGAT LANSIA MELALUI KEGIATAN BUDAYA SENI
}

\section{(SPURING THE SPIRIT OF ELDERLY THROUGH CULTURAL ACTIVITIES)}

\author{
Sri Wiryanti Budi Utami ${ }^{1}$, Tubiyono ${ }^{2}$, Puji Karyanto ${ }^{2}$ \\ ${ }^{1,2,3}$ Prodi Bahasa dan Sastra Indonesia, Fakultas Ilmu Budaya Universitas Airlangga \\ e-mail: oetami_yanti@yahoo.co.id
}

\begin{abstract}
Age does not limit someone to continue working, independent, knowledgeable, capable and creative. With cultural activities can motivate the elderly to continue to develop creative power, so that the elderly life the rest of their lives full of enthusiasm and happiness. Cultural activities through elderly meetings which are held once every 2 weeks are certainly very useful to support their mental-spiritual health and encourage staying active. The Community Partnership Program is focused on singing and creating art. Basically, the synergy between the community and the elderly continues to be active and happy for the rest of their lives, which needs to be supported by universities as a source of expertise in science, technology and art (IPTEKS) that will accelerate the implementation and implementation of activities, because the three are an inseparable part.
\end{abstract}

Keywords: creative power, cultural activities, elderly

\section{abstrak}

Usia tidak membatasi seseorang untuk terus berkarya, mandiri, berilmu, cakap dan kreatif. Dengan kegiatan budaya dapat memotivasi lansia tetap mengembangkan daya kreatif, sehingga para lansia menjalani sisa hidupnya penuh semangat dan bahagia. Kegiatan budaya melalui temu lansia yang diadakan setiap seminggu 2 sekali tentu sangat bermanfaat menunjang kesehatan mental-spiritual mereka dan menyemangati tetap aktif. Program Kemitraan Masyarakat ini di fokuskan pada kegiatan bernyanyi dan berkarya seni. Pada dasarnya sinergi antara masyarakat dan para lansia tetap beraktivitas dan bahagia dalam sisa hidupnya perlu didukung oleh Perguruan Tinggi sebagai penyedia sumber kepakaran ilmu pengetahuan, teknologi dan seni (IPTEKS) akan mempercepat pelaksanaan dan implementasi kegiatan, karena ketiganya merupakan bagian yang tidak terpisahkan.

Kata kunci: daya kreatif, kegiatan budaya, lansia

\section{PENDAHULUAN}

Jumlah umur lanjut usia di lingkungan RW 04 Kelurahan Rungkut Menanggal, Kecamatan Gunung Anyar cukup signifikan untuk mendapat perhatian serius agar tidak membebani keluarga dan lingkungan. Jumlah lansia di RW 04 tercatat 380 orang. Masih cukup banyak lansia aktif dalam acara temu lansia yang diadakan setiap dua kali seminggu dalam acara kebugaran rohani dan jasmani, seperti acara pengajian, olah raga, dan priksa kesehatan. Tecermati pada acara-acara tersebut dihadiri oleh lansia dalam kisaran 60 sampai 80 orang. Apalagi pada acara wisata lansia yang diadakan setiap satu tahun sekali, selalu diikuti hampir 150 orang. Hal in menunjukkan bahwa lansia masih membutuhkan perhatian, kebahagiaan, dan kesehatan mental-spiritual. 
Dari acara temu lansia yang diselenggarakan tecermati banyak lansia yang berkeinginan untuk aktif dalam berbagai kegiatan. Masih banyak kegiatan positif yang mereka lakukan seperti menunjukkan kebolehan 'bernyanyi' dan sangat 'antusias' mengikuti berbagai penyuluhan kesehatan. Menurut mereka berkumpul, berbagi pengalaman sambil mendapat pengetahuan merupakan sesuatu yang masih dibutuhkan dalam menjalani sisa hidupnya.

Lansia di lingkungan RW 04 rata-rata berasal dari pensiunan karyawan dan pegawai negeri. Lansia dan masa pensiun merupakan dua hal yang menurut mereka harus dihadapi dengan tetap beraktivitas bila tidak ingin cepat 'pikun'. Oleh karena itu, mereka sangat 'antusias' mengikuti berbagai acara yang diselenggarakan 'kampung'. Secara 'finansial', para lansia di RW 04 berkecukupan. Mereka tidak lagi membutuhkan penambahan ekonomi, yang mereka inginkan adalah ketentraman, kesejahteraan batin dalam menjalani masa lansia. Oleh karena itu, kegiatan budaya merupakan kegiatan yang cocok dan tepat untuk lansia yang secara 'finasial' tergolong cukup. Melalui kegiatan budaya, lansia masih dapat dan mampu menyalurkan daya kreativitas yang membuat mereka bahagia dan siap menghadapi tantangan yang dihadapkan dalam menjalani sisa hidupnya. Melalui kegiatan budaya, mereka juga mendapatkan pengalaman dan belajar tentang konsekuensi dari, misalnya, hidup menyendiri, senangnya berbagi dan bahayanya mengikuti 'gossip' orang banyak.

Relevansi Program Kemitraan Masyarakat pada lansia sejahtera RW 04 Kelurahan Rungkut Menanggal Kecamatan Gunung Anyar Surabaya melalui kegiatan budaya sebagai Tema Pengabdian Masyarakat bertujuan menyelenggarakan program kegiatan dan peluang yang belum dimanfaatkan oleh lansia, yang memberikan kesempatan dan mengajak mereka untuk tetap bisa berkarya, mandiri, bahagia dan sehat secara mentalspiritual. Menggunakan kegiatan budaya sebagai alat untuk belajar dan berlatih keterampilan tertentu akan menyenangkan, di sisi lain tetap melatih keterampilan motorik, ingatan, konsentrasi yang menghambat kepikunan, dan tetap terjaga kesehatan mental-spiritualnya.

Menua adalah suatu kondisi yang dialami oleh seseorang saat mereka mulai memasuki masa lanjut usia. Maryam (2008) mengklasifikasikan orang lanjut usia menjadi lima, yang meliputi: prausia lanjut (45-59 tahun), usia lanjut (60 tahun ke atas), usia lanjut resiko tinggi (usia 60-70 tahun dengan masalah kesehatan), usia lanjut potensial (usia lanjut yang masih mampu melakukan aktivitas) dan usia lanjut tidak potensial (usia lanjut yang hidupnya bergantung pada bantuan dari orang lain). Di tahun 2016 terdapat sekitar 22 juta orang lanjut usia di Indonesia. Populasi orang lanjut usia terus meningkat, jika dibandingkan jumlah orang lanjut usia sebanyak 17 juta pada tahun 2006 dan 13.5 juta orang pada tahun 1996 (United Nations, Population Division of the Department of Economic and Social Affairs of the United Nation Secretariat, 2016). Peningkatan jumlah orang lanjut usia sebesar 26\% (1996-2006) dan 29\% (2006-2016) menunjukkan pentingnya memberikan perhatian pada orang yang termasuk dalam lanjut usia, karena populasi mereka yang cukup besar hampir 9\% dari total populasi penduduk Indonesia. Dalam konteks ini tentunya pemberdayaan dengan memotivasi eksperimentasi dan kreasi lansia sebagai hasil dari kreatifitasnya sendiri yang dapat memberikan kebahagiaan dan kebanggaan perlu dilakukan. 
Pemberdayaan sebagai proses menstimulasi, mendorong atau memotivasi individu agar mempunyai kemampuan atau keberdayaan untuk menentukan apa yang menjadi pilihannya (Pranarka dan Prijono 1996). Kegiatan Budaya dapat meliputi kegiatan yang berkaitan dengan tari, musik, drama, seni rupa dan kerajinan (termasuk seni lukis dan seni pahat) dan bercerita. Kegiatan budaya merupakan alat penting yang dapat membantu untuk menolong lansiamengaktualisasi diri dengan meraih pengalaman dan kompetensi sosial dan emosionalnya. Kompetensi sosial dan emosional tidak hanya penting untuk kesejahteraan, juga dapat mencegah dan mengurangi perasaan tidak berharga.

Secara filosofis, community development mengandung makna 'membantu masyarakat agar bisa menolong diri sendiri', yang berarti bahwa substansi utama dalam aktivitas pembangunan masyarakat adalah masyarakat itu sendiri. Dengan demikian, pemberdayaan masyarakat sebenarnya adalah sebuah konsep pembangunan ekonomi dan politik yang merangkum berbagai nilai sosial. Konsep ini mencerminkan paradigma baru pembangunan, yakni yang bersifat "people centered, participatory, empowering, and a sustaniable" (Chambers 1995).

Kegiatan budaya sebagai penanganan kepada lanjut usia berpedoman pada undangundang no 13 tahun 1998 pasal 5 ayat 2 menerangkan bahwa sebagai penghormatan dan penghargaan kepada lanjut usia diberikan hak untuk meningkatkan kesejahteraan sosial yang meliputi: 1) pelayanan keagamaan dan mental spiritual; 2). Pelayanan kesehatan; 3). pelayanan kesempatan kerja; 4)pelayanan pendidikan dan pelatihan; 5)kemudahan dalam penggunaan fasilitas, sarana, dan prasarana umum; 6). kemudahan dalam layanan dan bantuan hukum; 7)perlindungan sosial; dan 8)bantuan sosial.

Pemberdayaan kepada lansia digunakan untuk memberi semangat, motivasi agar seseorang dapat berkembang secara maksimal sesuai dengan potensi yang dimiliki. Kindervatter (1979) pemberdayaan adalah upaya penyadaran dan peningkatan dayadaya pada diri seseorang atau kelompok untuk memahami dan mengontrol dimensidimensi kekuatan yang dimiliki (religi, fisik, psikis, sosial,ekonomi, politik dan budaya) untuk peningkatan keduduakan mereka di dalam masyarakat. Memberdayakan lansia melalui kegiatan budaya merupakan bidang yang termasuk dalam pelayanan pendidikan dan pelatihan maupun pelayanan kesehatan. Bidang pelayanan pendidikan dan pelatihan merupakan salah satu hak penduduk lanjut usia, karena pendidikan dan pelatihan bisa dilakukan tidak terbatas pada usia. Dalam meningkatkan kesejahteraan lanjut usia pendidikan dan pelatihan budaya bisa dilakukan untuk memberdayakan dan juga membuat lanjut usia bisa berdaya, mandiri, cakap, dan tidak kalah pentingnya membuat sehat mental sosial-spiritual, bahagia dan bangga karena masih mampu berkreativitas dalam berkarya.

Pendidikan non-formal sesungguhnya merupakan pendidikan sepanjang hayat (life long education). UNESCO Institut for Education (1979) menegaskan prinsip-prinsip yang memberikan arah sehingga pendidkan luar sekolah dikembangkan, yaitu: 1) pendidikan hanya berakhir apabila manusia telah meninggalkan dunia fana ini, 2) pendidikan sepanjang hayat merupakan motivasi yang kuat bagi peserta didik untuk merencanakan dan melakukan kegiatan belajar secara terorganisasi dan sistematis, 3) kegiatan belajar ditujukan untuk memperoleh, memperbaharui, dan atau meningkatkan pengetahuan, 
sikap dan keterampilan yang telah dimiliki dan, mau tidak mau, harus dimiliki oleh peserta didik atau masyarakat berhubungan dengan perubahan yang terus menerus sepanjang kehidupan, 4) pendidikan memiliki tujuan-tujuan berangkai dalam mengembangkan kepuasan diri setiap insan yang melakukan kegiatan belajar, 5) perolehan pendidikan merupakan prasyarat bagi perkembangan kehidupan manusia, baik untuk memotivasi diri maupun untuk meningkatkan kemampuannya, agar manusia melakukan kegiatan belajar guna memenuhi kebutuhan belajarnya, dan 6) pendidikan luar sekolah mengakui eksistensi dan pentingnya pendidikan sekolah serta dapat menerima pengaruh dari pendidikan sekolah karena kehadiran kedua subsistem ini untuk saling melengkapi dan saling mendukung antara yang satu dengan yang lainnya.

Kegiatan budaya yang memotivasi eksperimentasi dan kreasi lansiamerupakan bentuk pendidikan sepanjang hayat. Selain itu, menyikapi bahwa pendidikan tidak hanya terbatas pada usia produktif saja, lebih dari itu pendidikan bisa dilakukan sejak dini sampai usia lanjut atau sampai akhir hayat. Kegiatan budaya senimerupakan upaya pendidikan luar sekolah sampai akhir hayat yang dapat diimplementasikan terhadap para lanjut usia. Pendidikan seumur hidup yang tidak mengenal strata dan usia membantu masyarakat untuk selalu hidup dalam proses belajar. Dari beberapa pengertian tersebut, maka PKM (Program Kemitraan Masyarkat) yang memfokuskan pada lansia sejahtera memalui kegiatan budayamerupakan salah satu wujud pendidikan sepanjang hayat dalam rangka memenuhi hak lansia untuk meningkatkan kesejahteraan lanjut usia yang salah satu haknya adalah mendapatkan pelayanan pendidikan dan pelatihan. Orang lansia akan merasa bahagia bila mereka masih dapat melakukan banyak aktivitas. Merupakan suatu tindakan yang bijaksana jika program kegiatan untuk memberi kesempatan pada lanjut usia melakukan kegiatan apa saja yang disukainya sehingga tetap menjaga harga diri, martabatnya serta merasa dirinya berguna untuk yang lain.

Banyak hal yang diinginkan oleh lanjut usia untuk tetap produktif serta berbaur ditengah masyarakat antara lain semangat yang ada pada diri lanjut usia, adanya rasa dihormati dengan keberadaannya di tengah masyarakat sekitarnya, tidak merasa tersisihkan dan lain sebagainya. Oleh karena itu, sepatutnya, para lansia yang masih produktif tetap diberi motivasi untuk berkegiatan produktif dan membahagiakan dirinya. Kegiatan dalam konteks budaya seni ini diharapkan dapat memberikan pengalaman batin para lansia dan mengurangi pandangan-pandangan keliru tentang lanjut usia yang selalu diidentikan dengan suatu kelompok masyarakat yang rapuh dan menjadi beban orang lain. Hasil kegiatan dan peran lansia di masyarakat merupakan dua hal yang dapat menghapus pandangan masyarakat terhadap mereka sebagai beban lingkungan. Di sisilain masyarakat tetap menghargai dan memberikan ruang terhadap lanjut usia beraktivitas, berkreasi dan membahagiakan.

\section{METODE PENGABDIAN MASYARAKAT \\ Identifikasi Permasalahan Prioritas Mitra}

Terkait dengan identifikasi permasalahan prioritas mitra, ada beberapa hal yang menjadi permasalahan mitra yang perlu segera diberikan solusinya dalam kegiatan budaya adalah: 1) Mempersiapkan fasilitas terlaksananya kegiatan budaya, khususnya dalam seni vokal, seni lukis, seni merangkai bunga, dan seni olah makanan; 2) Memotivasi lansia potensial mengambil kesempatan dalam kegiatan budaya ini sesuai 
bakat dan minat dari kegiatan yang diselenggarakan; 3) Memberi informasi yang menjelaskan kondisi input, proses dan produk dari Program Kemitraan Masyarakat yang terkait dengan bidang budaya.

\section{Tahap Perencanaan}

Pada tahap perencanaan dilakukan pengamatan lingkungan untuk mengidentifikasi kebutuhan lansia. Prioritas kebutuhan lansia yang utama adalah tersedianya lingkungan yang layak untuk melaksanakan pertemuan dan kegiatan rutin temu lansia. Setelah ditemukan prioritas kebutuhan lansia, maka tim pelaksana mendesain program kegiatan budaya.

Lokasi pelaksanaan kegiatan ditetapkan di 'gazebo RW 03 Kelurahan Rungkut Menanggal, Kecamatan Gunung Anyar. Setelah penetapan lokasi, tim pelaksana membuat surat perijinan dan perjanjian kerjasama dengan RW dan Kelurahan setempat

\section{Tahap Pelaksanaan}

Metode pelaksanaan program Kegiatan Kepada Masyarakat (PKM) diawali dengan observasi situasi subjek sasaran. Observasi ini untuk mengetahui interaksi dan kondisi lansia. Pelaksanaan observasi ini ditempuh dengan interview dengan tokoh masyarakat dan ketua organisasi lansia.

Dalam kaitannya mengajak partisipasi lansia dalam kegiatan program PKM ditempuh pendekatan sebagai berikut: 1) Pendekatan terhadap tokoh kunci (Personal Approach). Metode ini dilaksanakan dengan pendekatan terhadap tokoh kunci yaitupengurus lansia dan lansia aktif; 2) Pendekatan partisipatif (Partisipative Approach). Metode ini digunakan untuk mendukung realisasi program yang direncanakan dengan melibatkan lansia untuk menumbuhkan rasa percaya diri bahwa mereka masih berdaya dalam menyalurkan kreativitas dalam kegiatan budaya. Di samping itu, metode partisipatoris dapat menumbukan kemadirian dalam menentukan kegiatan budaya yang mereka inginkan Metode partisipatoris ini diterapkan dengan pentahapan sosialisasi, tutorial kegiatan budaya, pengelompokan minat lansia dalam kreativitas budaya seni, praktik kegiatan sesuai minat lansia dalam menuangkan pengetahuan dan keteramplanyang sudah diperoleh selama tutorial; 3) Pendampingan. Metode ini digunakan untuk memupuk rasa percaya diri lansia dalam berkreativitas budaya seni dan menghasilkan produk yang membahagiakan dan membanggakan. Selain itu, agar pelaksanaan program kegiatan budaya sesuai target yang diharapkan; 4) Evaluasi dilakukan sebagai wujud akuntabilitas dan transparansi baik dalam pengelolaan keuangan dan administrasi maka pelaporan segera dilakukan disertai bukti fisiknya.

\section{Tahap Pemantauan}

Setelah program kegiatan berjalan, perlu dilakukan analisis program guna mengetahui factor penunjang dan penghambat keberlangsungan program dan kemudian dicarikan solusinya.

\section{HASIL DAN PEMBAHASAN}

Kreativitas tidak mengenal batas usia. Anak-anak, remaja, dewasa, lansia, berhak menyalurkan keatifitas dalam hal yang positif. Banyaknya waktu luang dapat dijadikan sebagai peluang usaha. Peluang usaha ini dapat menjadi terobosan baru dalam usaha 
dan meningkatkan kesejahteraan warga RW empat kelurahan Rungkut Menanggal kecamatan Gunung Anyar, Surabaya.

Kegiatan Penguatan Daya Kreatif Lansia Sejahtera ini dilakukan dalam lima kali pertemuan dengan tujuan menyejahterakan lansia. Terus bertambahnya umur akan lebih bermanfaat dengan diisi kegiatan-kegiatan yang positif. Kegiatan yang dilakukan bersama-sama dapat membangkitkan semangat dan kerukunan warga. Kegiatan ini mendapat respon positif dari warga. Terbukti dengan antuasiasme dan semangat peserta yang tidak hanya didominasi oleh ibu-ibu. Bapak-bapak juga antusias untuk mengikuti kegiatan melukis, merangkai bunga, dan paduan suara.

Diharapkan kegiatan ini dapat menambah pengetahuan, membangkitkan semangat untuk terus berkreasi dan membangkitkan kesejahteraan dengan memberikan pelatihan sebagai peluang usaha yang cukup menjanjikan. Pembimbing dalam setiap kegiatan merupakan orang yang ahli di bidangnya. Pelatihan yang berkelanjutan dan pembimbing yang ahli dibidangnya dapat menghasilkan karya yang maksimal.

Pensejahteraan lansia dengan budaya Seni yang memanfaatkan daya kreativitas dibagi menjadi empatk kegiatan besar, kegiatan memasak yang memberikan manfaat pada para anggota lansia untuk berkreasi dalam mengolah bahan-bahan yang sudah ada menjadi menu yang baru. Kegiatan merangkai bunga membantu para anggota lansia untuk dapat berkreasi dalam penataan serta penggunaan pola merangkai bunga. Kegiatan melukis bermanfaat untuk menyalurkan seni para anggota dan dapat menjadi pelung bisnis, seperti melukis di media tas, dompet, kerudung, dan lai-lain yang dapat dijual. Dan terakhir kegiatan paduan suara yang berfungsi sebagi penyaluran hobi menyanyi untuk para anggota lansia.

\section{Kegiatan Memasak}

Memasak merupakan kegiatan yang sudah biasa dilakukan oleh ibu-ibu rumah tangga. Kegiatan yang sudah biasa dilakukan ini dapat menjadi kegiatan berbayar dengan peningkatan kemampuan dan penambahan pengetahuan sesuai perkembangan zaman. Kegiatan memasak ini dikoordinir oleh pemilik Dewi catering selain itu, juga mendatangkan chef untuk membantu menjelaskan teknik masak yang benar. Bahan yang sederhana dapat diolah menjadi makanan berharga cukup tinggi dengan penambahan bahan dan bumbu.

Waktu pelatihan yang singkat menjadi alasan untuk pemberian resep. Pada umumnya resep diberikan sebelum praktik pelatihan dan berlanjut dengan praktik. Cara ini dipilih untuk efisiensi waktu agar dapat selesai sesuai dengan harapan. Menu masakan dipilih sesuai selera pasar agar bisa menjadi komuditas olahan yang bisa dijual dengan penambahan dan penampilan yang menarik. Pemilihan bahan masakan dipilihkan oleh pembimbing dengan pertimbangan gizi, manfaat, ketersediaan, dan kemudahan dalam mengolah. Beberapa pertimbangan tersebut menjadi dasar pelatihan untuk memudahkan dalam proses kegiatan memasak. Sehingga menu masakan yang dipilih salah satunya yaitu, dimsum dan sup creamy labu kuning, dimsum dipilih oleh koordinator kegiatan ini agar para lansia dapat menggunakan dimsum sebagai pelung usaha, karena dengan bahan dan cara pengolahan yang mudah. Sup creamy labu kining juga dipilih dengan 
mempertimbangkan bahan yang mudah didapat serta gizi, dan bertujuan agar para lansia yang mengikuti kegiatan ini dapat berkreasi dalam hal memasak.

Para anggota lansia sangat antusias ketika mendapatkan pengetahuan tentang teknik memasak yang baik dan benar, ditambah koordinator yang menjelaskan sangat bersahabat dan menggunakan kata-kata yang mudah dimengerti. Sehingga para anggota lansia yang mengikuti kegiatan memasak ini sangat senang baik secara fisik maupun psikologi.

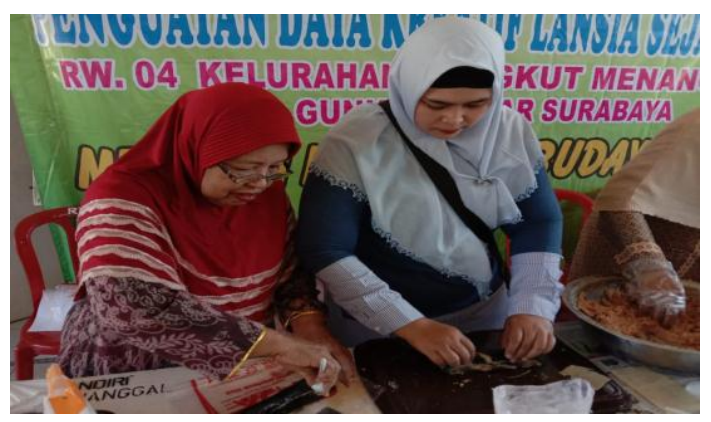

Gambar 1. Kegiatan Mengolah Makanan Dimsum

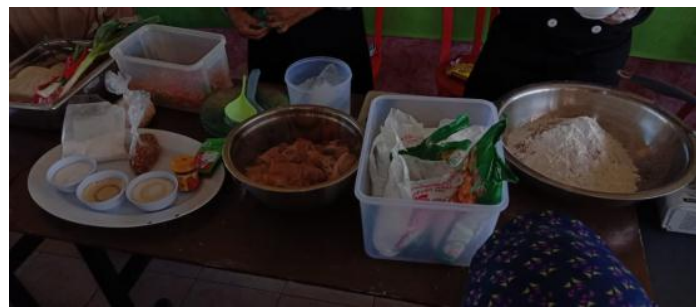

Gambar 2. Bahan-Bahan Kegiatan Memasak

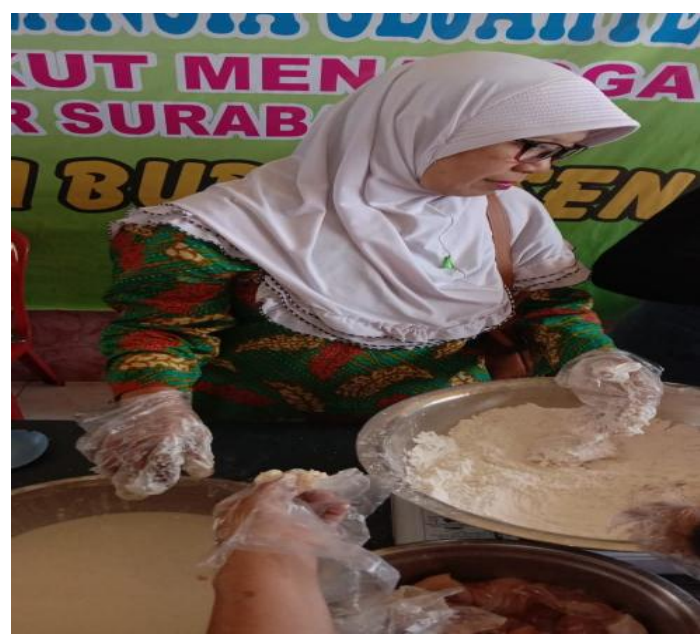

Gambar 3. Kegiatan Mengelolah Makanan Ayam Geprek 


\section{Kegiatan Merangkai Bunga}

Merangkai bunga bukan merupakan kegiatan yang sulit untuk dilakukan. Sudah menjadi rahasia umum bahwa bunga adalah simbol dari keindahan. Keindahan yang diberikan oleh bunga dapat menjadi lebih indah dengan penambahan vas, daun, dan batang. Penataan yang baik juga dapat memberikan nilai keindahan yang lebih teratur dan menarik. Proses penataan ini yang membutuhkan dasar dari pembimbing dan kreasi dari peserta.

Bahan dan Modul dalam merangkai bunga sudah disiapkan oleh pembimbing. Modul digunakan untuk membantu dalam proses perangkaian sesuai dengan contoh. Setelah semuanya berhasil menyesuaikan dan memiliki dasar dalam proses perangkaiannya akan diberikan kebebasan untuk berkreasi sesuai dengan keinginan peserta pelatihan.

Proses perangkaian bunga menggunakan teknik yang diajarkan langsung oleh pembimbing yang sudah berpengalaman dan menjadi bagian dari IPBI (Ikatan Perangkai Bunga Indonesia). Teknik yang digunakan dalam pelatihan untuk lansia ini menggunakan teknik yang seerhana agar dapat diikuti oleh peserta dengan hasil yang maksimal. Hasil rangkaian bunga dapat langsung dibawa pulang oleh peserta. Selain itu peserta diajarkan tekni-tekni merangkai bunga dan bentuk rangkaian bunga.

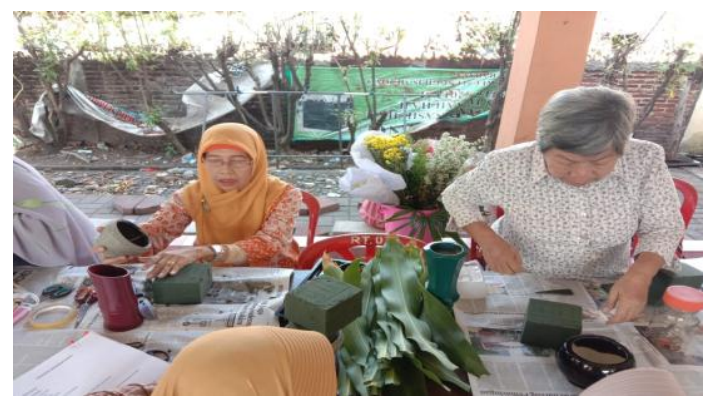

Gambar 4. Pemilihan Pola Dalam Kegiatan Merangkai Bunga

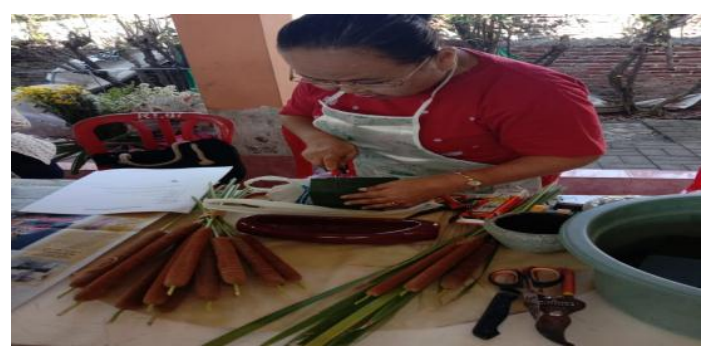

Gambar 5. Pembentukan Pola Dalam Kegiatan Merangkai Bunga 


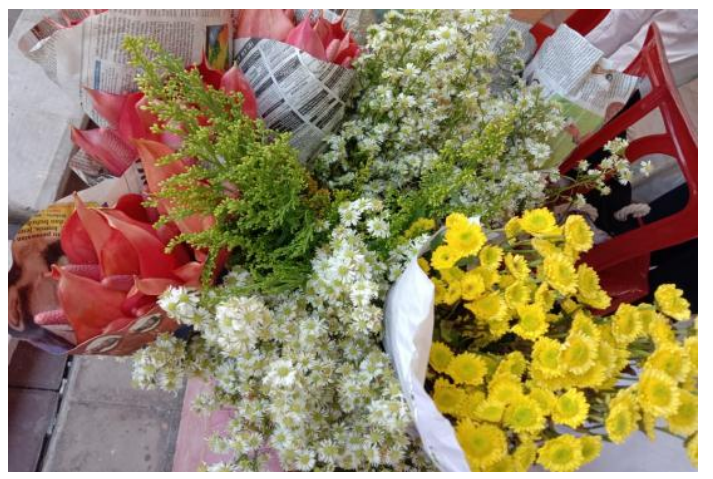

Gambar 6. Bahan Kegiatan Merangkai Bunga

\section{Kegiatan Melukis}

Kegiatan yang sering dianggap sulit karena hanya orang-orang tertentu yang dapat melakukannya ini ternyata dapat menjadi kegiatan yang menyenangkan untuk dipelajari. Semangat belajar dan kesabaran sangat dibutuhkan dalam pembuatan lukisan. Teknik melukis dapat dipelajari dan dipraktikkan dengan mudah karena dibimbing oleh orang yang sudah berpengalaman dibidangnya.

Cat akrilik dipilih untuk memudahkan proses pewarnaan sebagai pemula. Lukisan ini dapat digunakan dalam berbagai media diantaranya, kerudung, baju, tas, taplak meja, dompet, tempat handphone, dan kanvas. Pelatihan lebih ditekankan pada teknik dalam perubahan warna atau degradasi. Perbedaan warna dibutuhkan untuk menegaskan bentuk tiga dimensi. Bentuk tiga dimensi dapat memberikan kesan hidup pada objek yang dilukis. Hasil karya diberikan kepada peserta secara langsung.

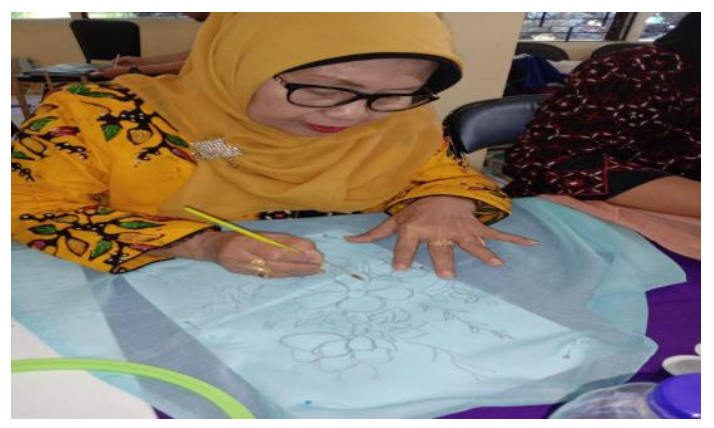

Gambar 7. Kegiatan Melukis Dengan Medium Kerudung

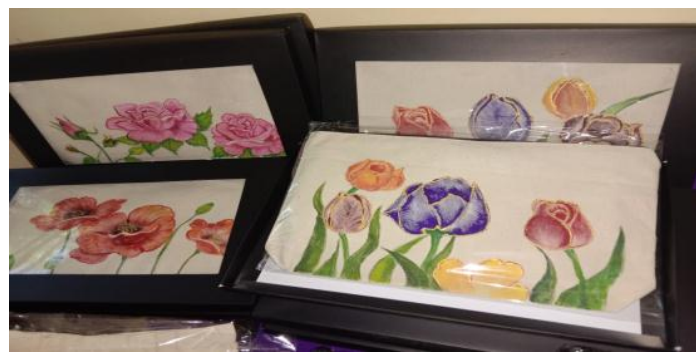

Gambar 8. Hasil Melukis dari Media Tas 


\section{Kegiatan Paduan Suara}

Harmonisasi dibutuhkan untuk menghasilkan suara yang padu dan enak didengar. Kelompok paduan suara biasanya terbagi menjadi tiga bagian, yakni suara sopran, tenor, dan bas. Ketiga bagian tersebut saling melengkapi dan saling mengisi. Teknik pengajaran yang digunakan dalam pelatihan ini dilakukan dengan sederhana tanpa menggunakan pengklasifikasian jenis vokal. Hanya ada pengelompokan untuk nada tinggi dan rendah. Lagu yang digunakan sebagai pengelompokan nada adalah lagu Tanah Air ciptaan Ibu Sud.

Lagu yang sempat didengarkan ketika latihan ada dua, yaitu Mother dan Wanita Indonesia. Kegiatan ini bertujuan untuk menyalurkan bakat, hobi, dan mengisi waktu luang. Bernyanyi juga dapat menyalurkan emosi dengan cara yang positif. Bernyanyi dalam kelompok tidak diharuskan untuk mempunyai suara yang bagus. Akan tetapi pembimbing mengajarkan sikap-sikap untuk memperoleh nada dan suara yang harmonis.

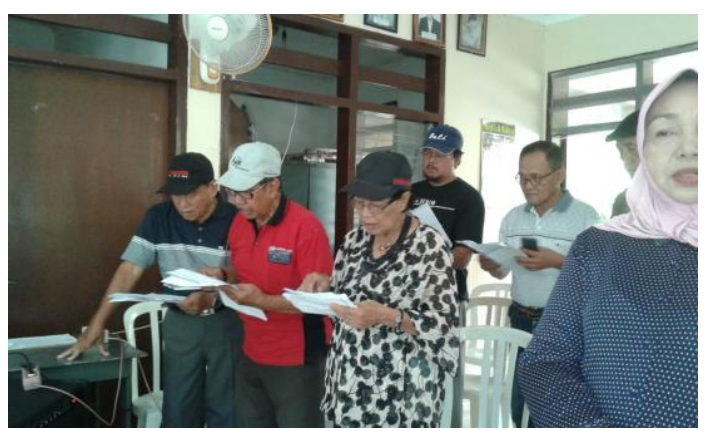

Gambar 9. Kegiatan Olah Vokal 1

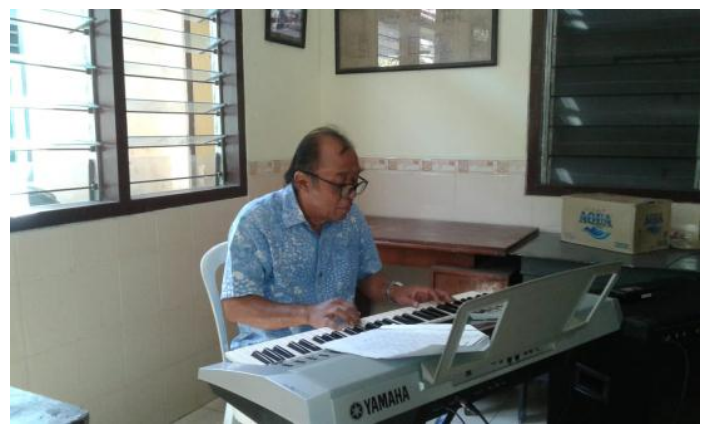

Gambar 10. Kegiatan Olah Vokal 2

\section{Kegiatan Bazar Sebagai Unjuk Kebolehan Para Lansia}

Semangat kemerdekaan Indonesia terlihat setiap bulan Agustus tiba. Bahkan satu bulan sebelumnya sudah banyak bermunculan rencana kegiatan-kegiatan yang bertema kemerdekaan. Kemerdekaan bukan hanya diartikan dengan sebuah kebebasan dari penjajahan, namun kemerdekaan juga dapat diartikan sebagai kebebasan untuk menuangkan ide, gagasan, kreatifitas, dan loyalitas warga negara kepada negara yang dicintainya.

Mengikuti sebuah acara penyambutan atau perayaan kemerdekaan merupakan bukti kecil adanya perhatian dan kepedulian warga negara kepada negaranya. Perjuangan para pahlawan menjadi bagian penting dari kisah perjalanan sejarah bangsa. Sejarah akan 
selalu mencatat semua yang dilakukan. Semua yang kita lakukan sekarang pada saatnya nanti juga akan menjadi sejarah. Sejarah yang baik diharapkan akan menghasilkan generasi yang lebih baik dan sejarah yang buruk diharapkan menjadi nasihat dan peringatan.

Peran warga negara sangat dibutuhkan dalam hidup berbangsa dan bernegara. Jumlah warga negara yang besar berpotensi untuk menghasilkan ide, gagasan, dan karya yang besar pula. Ide, gagasan, dan karya besar tidak hanya mampu dihasilkan dari orangorang yang berpendidikan tinggi, berusia produktif, dan bermodal besar. Usia lanjut atau lansia pun masih mampu memberikan kontribusi yang membanggakan untuk negara.

Hasil karya lansia tidak kalah dengan karya para pemuda. Kreatifitas para lansia dapat disalurkan dan dikembangkan melalui kegiatan PKM yang dilaksanakan oleh Universitas Airlangga bekerja sama dengan warga RW 04 Kelurahan Rungkut Menanggal Kecamatan Gunung Anyar Surabaya. Hasil karya para lansia diikutsertakan dalam acara penyambutan kemerdekaan Indonesia ke-74. Pameran hasil karya para lansia mendapat respon positif dari masyarakat yang mengikuti acara tersebut.

Dua kegiatan PKM yang ditampilkan adalah kreatifitas pelatihan memasak dan kreatifitas pelatihan melukis. Keduanya berhasil menyita perhatian pengunjung dan banyak yang turut serta dalam kegiatan memasak dan membeli hasil karya lukisan di beberapa media seperti tas, kerudung, kanvas, talenan, dan lain sebagainya. Antusiasme pengunjung menjadi bukti masih berperannya para lansia dalam mengisi kemerdekaan dan masih adanya peluang untuk mengembangkan kreatifitas dan menciptakan peluang usaha yang cukup menjajikan bagi para lansia. Terutama dalam karya lukis dari berbagai jenis medium seperti bag, telnan, kerudung, dan lain-lain dari hasil program pelatihan melukis dalam kegiatan PKM pensejahteraan lansia ini dapat menghasilkan keutungan yang cukup banyak dalam kegiatan bazar, sehingga dapat dibuktikan bahwasanya dengan pelatihan program pensejahteraan lansia memiliki manfaat psikis dan manfaat finansial, tidak hanya kebahagiaan dan suka cita para lansia dapat menyalurkan hobi dalam program-program yang ada dalam kegiatan PKM pensejahteraan lansia, para anggota lansia juga dapat membuka peluang usah bisnis melalui kegiatan ini. Sehingga para lansia dapat mandiri dan tidak terbatas oleh umur

Wujud semangat dan kreatifitas ini akan semakin baik, jika ada rencana berkelanjutan dan pengelolaan serius dari pihak-pihak yang diharapkan dapat memberikan peluang dan tempat untuk menunjang serta meningkatkan kualitas hasil karya dari para lansia. Harapan itulah yang juga menjadi tujuan dilaksanakannya PKM ini. Semoga kegiatan ini dapat menjadi tambahan catatan sejarah yang baik dan dapat dilanjutkan serta memberikan ide-ide kegiatan lain yang bermanfaat. 


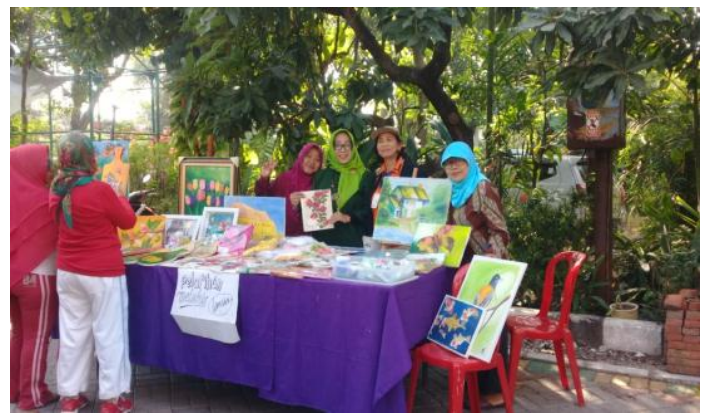

Gambar 11. Unjuk Kebolehan Dalam Kegiatan Bazar

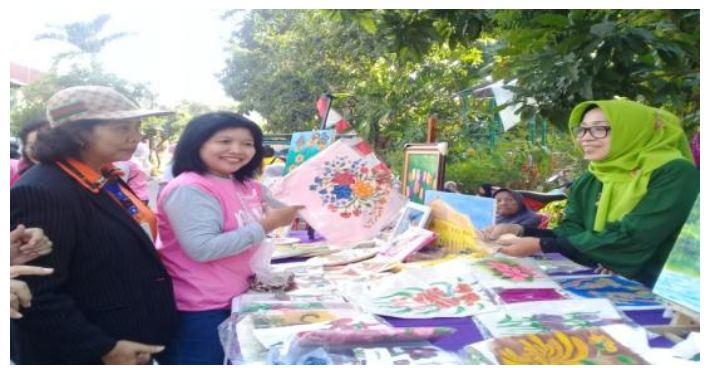

Gambar 12. Penjualan Hasil Kegiatan Melukis Dalam Kegiatan Bazar

\section{PENUTUP \\ Simpulan}

Kegiatan yang diadakan untuk pensejahteraan lansia memberikan dampak yang positif dan antusias para anggota. Antusiasme para anggota dapat terlihat melalui kegiatan yang diadakan. Pembimbing untuk setiap kegiatan memiliki kompentisi yang cukup dibidangnya, sehingga memudahkan penjelasan cara memasak, merangkai bunga, melukis, dan paduan suara kepada anggota. Para anggota sangat menyukai kegiatankegiatan yang diadakan karena pengisian waktu luang yang bermanfaat baik dalam penyaluran hobi maupun membukak peluang pekerjaan.

\section{DAFTAR PUSTAKA}

Chambers, Robert., (1995), Poverty and Livelihoods: Whose Reality Counts? IDS, Brighton,UK, IDS Discussion Paper, 347.

Kindervater, S. 1979. Nasional Education as an Empowering Process. Massachuseets: Cent. for Inter. Educational University of Massachuseets.

Maryam, S. (2008). Mengenal Usia Lanjut dan Perawatannya. Penerbit Salemba.

Peraturan Pemerintah Nomor 43 Tahun 2004. Tentang Pelaksanaan Upaya Peningkatan Kesejahteraan Lanjut Usia.

Pranaka, A.M.W. dan Prijono OS, 1996, Pemberdayaan: Konsep, Kebijakan, dan Implementasi, Jakarta, CSIS. 
Rand, Gunvor. 1981. Ulike teoretiske syn pa kreativitet (Different Theoretical Views of Creativity).University of Oslo

Undang-Undang Nomor 13 Tahun 1998. Tentang Kesejahteraan Lanju Usia.

United Nations, (2016). Population Division of the Department of Economic and Social Affairs of the United Nation Secretariat. 